\title{
Orthodox and heterodox economics in recent economic methodology
}

\author{
D. WADE HANDS \\ University of Puget Sound
}

\begin{abstract}
This paper discusses the development of the field of economic methodology during the last few decades emphasizing the early influence of the "shelf" of Popperian philosophy and the division between neoclassical and heterodox economics. It argues that the field of methodology has recently adopted a more naturalistic approach focusing primarily on the "new pluralist" subfields of experimental economics, behavioral economics, neuroeconomics, and related subjects.
\end{abstract}

Keywords: orthodox, heterodox, neoclassical, economic theory, economic methodology

JEL Classification: A12, B41, B49, B50

Myself when young did have ambition to contribute to the growth of social science. At the end, I am more interested in having less nonsense posing as knowledge (Frank Knight, 1956).

At the time I was finishing graduate school, there was no real "field" of economic methodology. There were of course methodological writings by influential economists (e.g., Robbins 1932, 1952; Friedman 1953; Samuelson 1964, 1965), but these works were seldom of the same intellectual quality as the research that had made these economists famous as economists. There were also brief discussions of economics in influential books on the philosophy of science (e.g., Hempel 1965,

AuTHOR's NotE: This paper began as a lecture delivered at the XVII Meeting on Epistemology of the Economic Sciences, School of Economic Sciences, University of Buenos Aires, Buenos Aires, Argentina, October 6-7, 2011. It was subsequently published in Perspectives on epistemology of economics: essays on methodology of economics (Lazzarini and Weisman 2012). It is reprinted here with the permission of the editors. I have made minor changes and updated the references, but I did not make any substantive changes to the argument in the original lecture. I would like to thank the many people who have made helpful comments on earlier versions of the paper and I would also like to thank the editors of the Erasmus Journal for Philosophy and Economics, particularly Luis Mireles-Flores, for suggesting it be reprinted here. 
Nagel 1961), but they focused on general problems associated with the human and social sciences, rather than with specific issues concerning economics. There were two recently published case studies in the philosophy of economics written by philosophers-Hausman (1981) and Rosenberg (1976)-but in general the field was almost as unpopular among philosophers as it was among economists. Finally, and perhaps most importantly, there was beginning to be a collection of dedicated books on economic methodology-Blaug 1980a; Boland 1982; Caldwell 1982; Hutchison 1981; Latsis 1976; Wong 1978; and a few others-but it was a relatively assorted collection of texts with little to suggest that these books would end up being the foundational texts for the inchoate field of economic methodology. All in all, at that time there seemed to be very little to encourage a young scholar thinking about an academic career in economic methodology or the philosophy of economics.

However that was a long time ago, and I am happy to be able to report that the situation today is much improved. There are now dedicated journals such as The Journal of Economic Methodology and Economics and Philosophy, as well as numerous journals specializing in the history of economic thought that frequently publish methodological research. There are also a number of research institutes and professional societies dedicated to the intersection of economics and philosophy around the world. It is now possible for a young scholar to specialize in research connecting economics and philosophy without necessarily feeling like they are jeopardizing the possibility of a successful academic career. Of course, this does not mean that such careers are easy, or that all is well within the field-i.e., "better" certainly does not imply "good". Particularly in the United States, the economics profession still seems to have little or no interest in elevating economic methodology to the status of a legitimate field of inquiry within the discipline of economics. The financial crisis and the associated questioning of the methodological foundations of macroeconomic theory, seems to have initiated a momentary warming of the relationship between mainstream economics and economic methodology, but who knows how serious the overtures are or how long they will last. Also, it is probably not a good sign that the profession considers economic methodology to be an inferior good in the traditional microeconomic sense: that is, one that economists consume more of when incomes fall. 
The last twenty or so years have also witnessed a significant change in the traditional relationship between "orthodox" and "heterodox" schools of thought within economics. For most of the second half of the 20th century the economic mainstream, the orthodoxy, consisted of neoclassical microeconomics combined with some version of macroeconomics (it was IS-LM Keynesian theory during the immediate post WW-II period, and new classical macroeconomics and real business cycle theory later). On the other hand, the periphery of the discipline was divided into a small number of self-consciously heterodox schools of thought: institutionalist, Marxist, Austrian, post-Keynesian, and others. There were two key features to this half-century long equilibrium in economic theorizing. First, there was a dominant orthodoxy based on neoclassical principles-prediction and/or explanation of economic phenomenon in terms of the coordinated equilibrium behavior of rational self-interested agents-and those principles were strictly enforced. If there were no maximizing agents in the model, then it was not mainstream, and for the majority of the profession, not scientific, economics. ${ }^{1}$ And second, those outside of the mainstream tended to be self-conscious members of some particular heterodox school. It was not simply a matter of there being a dominant mainstream and a disparate group of outsiders-not just the discipline's "insiders" and the "others"-there was a dominant neoclassical school and a number of different, but distinct and self-consciously identified, heterodox schools in the periphery. Very few economists were engaged in theorizing that was outside of the mainstream and yet also outside of any of these clearly-labeled heterodox groups.

This relationship seems to have changed during the last few decades. On one hand, many of the most important recent developments within economics have occurred within fields such as

\footnotetext{
${ }^{1}$ The maximizing agents were explicit in microeconomics; in macroeconomics there were always ongoing efforts to find "microfoundations"-ways of grounding the macro-theoretical concepts on neoclassical principles. Although it is clearly recognized that the new classical macroeconomics that became dominant at the end of twentieth century was motivated by the desire for microfoundations, it is less well-recognized that even during the immediate post WW II period when Keynesian ideas dominated macroeconomics, there were also ongoing efforts to "ground" Keynesian ideas like the consumption function, liquidity preference, and the marginal efficiency of capital in individual maximizing behavior. The relevant "microfoundations" were defined more broadly during the Keynesian than the new-classical period, and perhaps the latter was more successful than the former in reaching its microfoundational goals, but the profession's preference for grounding macroeconomic concepts on neoclassical microeconomic principles was clearly revealed even during the Keynesian period.
} 
experimental economics, behavioral economics, evolutionary economics, and neuroeconomics. These are fields that are not "orthodox" in the strict neoclassical sense-they often produce anomalous results that conflict with standard neoclassical theory and often characterized economic behavior in very non-neoclassical ways-but they are also not "heterodox" in the traditional sense either; they are not Marxist, or institutionalist, Austrian, and so on. For some of the economists working in these new research programs, their research provides a radical new (non-neoclassical) approach to the prediction and explanation of economic behavior, but even among those who are less radical-those who believe that some version of neoclassical theory will eventually be able to subsume these new developments-there still seems to be a consensus that the problems and anomalies these fields have identified are real and deserve the profession's attention. This is very different than had been the case for many of the criticisms traditionally raised by heterodox economists. The Marxian concern with the exploitation of the working class by the capitalist class, or the Veblenian distinction between business and industry, were for most mainstream economists, not real issues that deserved the attention of the discipline. This is very different from, say, the mainstream's response to the endowment effects, reference dependency, and other choice anomalies identified in the work of Daniel Kahneman, Amos Tversky, Richard Thaler, and others (see, e.g., Kahneman 2003; Kahneman, et al. 1991; Kahneman and Tversky 2000; Thaler 1980; Tversky and Kahneman 1991). ${ }^{2}$ These concerns matter to mainstream economists in a way that most traditional heterodox concerns did not. ${ }^{3}$

There may also be changes underway within macroeconomicschanges initiated by what many see as the discipline's failure to predict, explain, or offer effective solutions for, the recent financial crisis-but I will focus primarily on microeconomic developments. There are a number of reasons for this. First, as I will argue later, microeconomics-

\footnotetext{
${ }^{2}$ One argument for the acceptance of these issues might be that some of these problems were recognized by the neoclassical economists of the ordinal revolution early in the 20th century. I have written in detail about this (Hands 2006, 2010, 2011), but it cannot be an argument for the recognition of these problems by the neoclassical mainstream, because there is essentially no recognition by contemporary economists that these same issues were also raised by economists during the ordinal revolution.

${ }^{3}$ One suggestion for why this has been the case is that while this literature has challenged the descriptive-scientific adequacy of mainstream theory, it accepts the mainstream view of rationality, i.e., the normative theory of what one ought to do in order to be rational. See Heukelom 2014 for a detailed historical discussion of this, and Sent 2004 for some other possible reasons for the mainstream attention.
} 
individual choice theory in particular-is where much of the recent methodological research has been done-it is where the methodological action is, so to speak-and recent methodological research is the main focus here. Second, it is not at all clear at this point how, or if, macroeconomics will change. The changes taking place in microeconomics-whether they end up being revolutionary or reformist-have been ongoing for at least two decades and came mainly as a result of internal forces: the available laboratory and field evidence, new tools and ways of gathering data, and so forth. In the case of macroeconomics, the forces of change have been external-in the economy, not in economics-and have come quite quickly. The current crisis may end up having a profound impact on future macroeconomic theorizing in the way that the Great Depression did, but at this point that is not clear. Finally, given the particular features of the current crisis, if mainstream macroeconomics changes, it is possible that it will change back in the direction of Keynesian theory: not a new theory or a new methodological approach, but a revival of an earlier, and (at least on some readings of Keynes) once dominant, framework for macroeconomic analysis. This is quite different than in recent microeconomics where experimental and behavioral economists are now making it possible to do that which every influential methodological writer from John Stuart Mill, to John Cairnes, to Neville Keynes, to Lionel Robbins, to Milton Friedman, said was totally impossible-that is, experiments-and where neuroeconomics is adding new technology to render the previously immeasurable, now measurable. ${ }^{4}$ It is useful also to note that this broadening of the base of acceptable approaches within mainstream microeconomics has occurred commensurate with a decline in the number of economists self-identifying with the traditional heterodox schools. This is not to say of course that institutionalist economics, or Marxist economics, or other heterodox schools have completely disappeared, but simply that while there are many economists critical of mainstream neoclassical practice, those who are, seem to be focused on particular problems, applications, and tools, rather than self-identifying with any general heterodox school of thought. ${ }^{5}$

\footnotetext{
${ }^{4}$ Although it is certainly possible to combine developments in experimental and behavioral economics with an analysis of the macroeconomic crisis. See, e.g., Heukelom and Sent 2010.

${ }^{5}$ See Dow 2010, or Lee 2009, for an alternative reading of the current situation in heterodox economics.
} 
I want to explore this three-way relationship between orthodox economics, heterodox economics, and economic methodology during the last few decades. I will begin by characterizing how work in economic methodology related to orthodox and heterodox theory during (roughly) the period 1975-2000 and then turn to how this relationship has changed in recent years.

\section{ORTHODOX AND HETERODOX IN ECONOMIC METHODOLOGY: 1975-2000}

Unlike most fields within economics, economic methodology does not have a standardized framework for inquiry; there are a wide range of approaches, styles, tools (from philosophy and elsewhere), as well as a wide range of goals (what it is the methodological research is supposed to "do"). Given this, how can I, in the space available, do justice to the methodological literature of the period 1975-2000? The truth is, I cannot, and for those interested in a detailed discussion of this literature I suggest a survey such as Economic methodology: understanding economics as a science (2010) by John Davis and Marcel Boumans, or my own Reflection without rules (2001). My focus here will be much more modest. I will focus on the relationship between orthodox and heterodox economics in the work of two influential economic methodologists during the second half of the 20th century: Mark Blaug and Terence Hutchison. ${ }^{6}$ There were many others doing very different types of methodology during this period, but these two authors seem to be representative of the most influential work in the field (at least the work written by economists).

The first thing to notice about the methodological literature of this period is that it was based on what I have elsewhere called the "shelf of scientific philosophy" view of economic methodology (Hands 1994, 2001). Ideas from the (assumed given and stable) shelf of scientific philosophy were simply taken off the shelf and "applied" to the science of economics without reconfiguration or with much sensitivity to the peculiarities of the discipline. In the case of both Blaug and Hutchison, the relevant philosophical shelf was Popperian-based on Karl Popper's philosophy of science $(1959,1965,1994)$-and according to Popper in order to qualify as a real science a discipline needed to make bold

\footnotetext{
${ }^{6}$ A non-exhaustive list of their important contributions to the methodological literature includes: Blaug 1976, 1980a/1992, 1990, 1994, 2002, 2003; and Hutchison 1938, 1981, 1988, 1992, 2000, 2009.
} 
(falsifiable, non ad hoc) conjectures and subject those conjectures to severe empirical tests. ${ }^{7}$ Blaug and Hutchison both argued that while most economists claim to be engaging in this type of scientific activity, they in fact fail to do so: economists do not practice what they preach. Instead, economists are engaged in what Blaug called "innocuous falsificationism":

I argue in favor of falsificationism, defined as a methodological standpoint that regards theories and hypotheses as scientific if and only if their predictions are at least in principle falsifiable, that is, if they forbid certain acts/states/events from occurring [...] In addition, I claim that modern economists do in fact subscribe to the methodology of falsificationism: [...] I also argue, however, that economists fail consistently to practice what they preach: their working philosophy of science is aptly characterized as "innocuous falsificationism" (Blaug 1992, xiii).

Such Popperianism offered tough standards-standards that Blaug and Hutchison argued economists could have, and should have, lived up to, but seldom actually did. It was an economic methodology that demanded that economists clean up their act.

There are of course many well-documented problems associated with Popperian falsificationism-in general, as well as when specifically applied to economics-but that is not my topic here. ${ }^{8}$ The task here is not to evaluate these positions, but simply to try to characterize the general tone/attitude of the methodological discussion of this period (as represented by the work of Blaug and Hutchison) and relate it to orthodox and heterodox economics.

So what did the methodology of Blaug and Hutchison have to say about heterodox economics, or the relative scientific standing of orthodox and heterodox economics? On the face of it, quite a lot. Even a cursory examination of the methodological work of Blaug and Hutchison reveal that they directed a substantial amount of critical attention to

\footnotetext{
${ }^{7}$ Although it should be noted that neither Blaug nor Hutchison were entirely consistent about the substantive details of what a Popperian approach to economics would entail. For example, Blaug moved easily between advocacy of Popperian falsificationism and advocacy of Imre Lakatos's methodology of scientific research programs (MSRP). Although both approaches are broadly "Popperian", they are quite different in detail with Lakatos sharply differentiating his view from falsificationism, and Popper denying that MSRP was in any way Popperian. To be fair, it should also be noted that not all Popperians writing about economics (Larry Boland, for example) considered (or consider) falsificationism to be the proper interpretation of Popper's views.

${ }^{8}$ See Hands 2001, 275-304, or Hausman 1988.
} 
heterodox theory of all persuasions: Marxian, institutionalism, post- and fundamentalist-Keynesianism, neo-Ricardian/Sraffian, Austrian, URPEtype late-1960s radical economics, and others.

Blaug began his career with a methodologically-inspired historical study of Ricardian economics (Blaug 1958) and he frequently criticized later Ricardians like John Stuart Mill for relying on introspection, ignoring the empirical facts of the mid 19th century British economy, and constructing various "immunizing strategies" to insulate Ricardian economics from empirical falsification (Blaug 1980a/1992). The Sraffabased neo-Ricardians of the second half of the 20th century were also criticized on the same grounds, as well as for succumbing to "formalism" (Blaug 1990, 2009). ${ }^{9}$ Blaug spent a substantial amount of time criticizing the labor theory of value and tendency laws (such as the falling rate of profit) in Marxian economics for not being falsifiable (Blaug 1980b, 1990) and noted Popper's own remarks about the unfalsifiability of the Marxian system (Popper 1976). Not to neglect the other side of the political spectrum, Blaug also had harsh methodological words for Austrian economists, particular Ludwig von Mises (Blaug 1980a/1992).

Similarly, Hutchison's first book (Hutchison 1938) was primarily a methodological critique of Lionel Robbins's Nature and significance (1932/1952), but it focused on the Austrian influence in Robbins's work. Hutchison continued to criticize Austrian economics throughout his life (Hutchison 1981) and while, like Blaug, the main methodological villain was von Mises, he included others such as Friedrich Hayek as well (Caldwell 2009). Hutchison criticized Marxian economics on grounds similar to Blaug's (Hutchison 1981) as well as the Cambridgefundamentalist version of Keynesian economics (Hutchison 1981, 2009).

Based on all these criticisms, one might assume that Blaug and Hutchison used their Popperian methodology to defend the neoclassical mainstream against heterodox criticism. But that was not really the case. Both Blaug and Hutchison were just as critical of work in the neoclassical mainstream because it also was in conflict with the Popperian principles of bold conjectures and severe empirical tests. In particular, the formalist revolution which started during the 1950s and ended with the Arrow-Debreu abstract Walrasian general equilibrium theory that dominated microeconomics until quite recently, was harshly

\footnotetext{
${ }^{9}$ See Garegnani 2011, and Kurz and Salvadori 2011, for critical responses to Blaug on Sraffian economics.
} 
criticized by both Blaug (1980/1992, 1997, 2002, 2003) and Hutchison (1992, 2000). For example, Blaug called the 1954 paper on the existence of competitive equilibrium by Kenneth Arrow and Gerard Debreu "a cancerous growth in the very centre of microeconomics" (Blaug 1997, 3) and Debreu's 1959 Theory of value "the most arid and pointless book in the entire literature of economics" (Blaug 2002, 27). Hutchison was only slightly more positive in his appraisal, calling general equilibrium theory the substitution of "fantasy content for realistic, or relevant, content" (Hutchison 2000, 18). But the criticism of neoclassical economics did not stop at the abstract Arrow-Debreu version of the theory. In fact, Blaug's survey of economic methodology (1980a/1992) was a veritable litany of criticisms of various aspects of the dominant neoclassical theory, with the eight chapters of Part III going topic by topic through standard theory from consumer choice, to production theory, to general equilibrium, to international trade, and so on, pointing out in each case how the theory failed to meet Popperian standards for scientific adequacy and/or progress. The only aspect of the mainstream theory of the day that Blaug seemed to give a positive nod was Keynesian economics, and even there he was critical of the "Mickey Mouse versions of Keynes in the 1950s" (1980a, p. 221) as well as the fundamentalist Cambridge versions of Keynesian theory. Hutchison was not quite as aggressive in his critical stance, but he too was critical of the formalism and lack of relevance of much of the dominant neoclassical theory (Hutchison 1981, 1992, 2000). Like Blaug, he was not very clear about exactly what kind of economics would meet the tough Popperian standards, but he was clear that both the neoclassical mainstream and heterodox theory were methodologically problematic.

The bottom line is that the Popperian "shelf of scientific philosophy" methodology of Blaug and Hutchison set the epistemic bar so high that essentially no economic theory could pass the scientific test. Although both Blaug and Hutchison probably favored the orthodox theory of the day-at least in its more applied, non-Arrow-Debreu, formulations-over various heterodox alternatives, it was a weak and frankly not very wellarticulated preference since according to the methodological standards they endorsed, almost all economic theory was either unfalsifiable or false, and even the most serious empirical work was "like playing tennis with the net down" (Blaug 1980a, 256). The shelf of scientific philosophy approach was often defended as a "tough" approach to methodology, because it demanded compliance with a relatively strict set of 
methodological standards. For that reason it was often endorsed by those who sought to use it as a way to attack economic theories they did not support, but such a strategy was only effective as long as the critical fire was not turned back on one's own position (which, of course, it always could be). The toughness was explained as a kind of "tough love" because even though it was strict, it was ostensibly done in the interest of helping the economics profession be (epistemologically) all that it could be. Unfortunately, since no economic theory, orthodox or heterodox, really passed the test, the discipline was left without any guidance for how particular fields or models might be improved, or how the discipline's cognitive value could be increased at the margin.

The literature on economic methodology expanded significantly during the period 1975-2000-and for that we should be grateful since it helped establish economic methodology as a legitimate field-but it expanded in a way that prevented it from engaging in much constructive criticism, or in playing any significant role in the actual practice of economic theorizing, or in allowing orthodox theory to respond to the criticisms of heterodox economists (or vice versa) in any meaningful way.

\section{ORTHODOX AND HETERODOX IN ECONOMIC METHODOLOGY: THE RECENT LITERATURE}

John Davis, my co-editor of The Journal of Economic Methodology, and others, have suggested that the mainstream of disciplinary economics is no longer neoclassical: that the once dominant neoclassical framework has been replaced by a new, more pluralistic, mainstream which is more open to psychology, less individualistic, accommodates various types of path-dependencies, and allows for a much broader class of modeling strategies and tools (Colander 2000; Colander, et al. 2008; Davis 2006, 2008, Santos 2011). As David Colander, Richard Holt, and Barkley Rosser put it: "Economics is moving away from a strict adherence to the holy trinity-rationality, selfishness, and equilibrium-to a more eclectic position of purposeful behavior, enlightened self-interest, and sustainability" (Colander, et al. 2008, 31). The most important piece of evidence for this change is the type of research that is currently being published in the most highly ranked economics journals: the American Economic Review, Quarterly Journal of Economics, Economic Journal, and even (although perhaps to a lesser extent) in the Journal of Political Economy. Another piece of evidence for this is that thirty years ago, most of the various specialty areas of research and teaching-labor 
economics, environmental economics, public finance, managerial economics, international economics, and the like-were simply particular "applications" of the standard neoclassical utility and profit maximizing framework. Now each of these fields is more likely to employ particular tools and conceptual frameworks that are indigenous, and in some cases endemic, to the particular subfield. International economics is now more than Walrasian general equilibrium theory with countries A and B replacing individuals A and B, environmental economists now need to actually know something about the relevant biological science, and so forth. Of course much of economic education-particularly undergraduate education - is still dominated by the neoclassical framework, but defenders of the "neoclassical is dead" thesis have tried to explain this in terms of lags and the institutional structure of the discipline (Davis 2006).

It is also important to note that the work identified with the new more pluralistic mainstream is not only not strictly neoclassical, it is also not heterodox either. Although many of the issues and anomalies identified in this recent literature have also long been identified by economists working within the heterodox tradition-think of the institutionalist critique of neoclassical choice theory or the institutionalist emphasis on evolutionary change, or the post-Keynesian or Austrian emphasis on path-dependency and hysteresis-the economists working in these new fields do not generally self-identify with heterodox schools of thought. For example, the histories of behavioral economics produced by practitioners (e.g., Camerer and Loewenstein 2004) often note Herbert Simon, James Dusenberry, and a few others from the middle of the 20th century, but do not generally cite any authors from the traditional heterodox literature. So too for earlier precursors. Behavioral ideas have been traced to Adam Smith (Ashrof, et al. 2005), David Hume (Sugden 2006), Jeremy Bentham (Kahneman, et al. 1997), and William Stanley Jevons and Francis Edgeworth (Bruni and Sugden 2007), but not to authors such as Karl Marx, Friedrich List, J. A. Hobson, or Thorstein Veblen. If there is a new more pluralist mainstream forming, it is neither neoclassical nor heterodox.

Although I am not quite as convinced as many others that the mainstream is no longer neoclassical, I do think the trend is clearly in that direction, and more importantly here, I definitely believe that a substantial change has taken place within economic methodology. In my 
book Refection without rules (2001) I argued that economic methodology was moving away from the "shelf of scientific philosophy" and more in the direction of naturalism, context-specific inquiries, and research that draws on a wider range of intellectual resources than just the philosophy of natural science. That process was ongoing at the time and has surely continued, but what was not clear a decade ago is how changes in economics itself have also initiated changes in the way that economic methodology is done. The bottom line is that almost all of the real "action" within contemporary economic methodology is in precisely the fields that Davis and others point to as elements of the new, more pluralistic, mainstream: neuroeconomics, experimental economics, behavioral economics, evolutionary economics; and the associated new tools such as computational economics, agent-based modeling, and various new empirical techniques. Neoclassicism may not be dead, but it is no longer the focus of the cutting edge of methodological researchbut then nor is heterodox economics. Neither neoclassical nor heterodox economics are the main focus of recent methodological inquiry.

To provide some evidence for this claim about the recent methodological literature, let me just note a few of the methodological books published during the last few years that focus on a specific field, or small set of fields, within economics. A non-exhaustive list of such books would include those by Bardsley, et al. (2010), Guala (2005), Ross (2005), and Santos (2010). Notice that most of these books focus on experimental economics, but more importantly they all examine economic research in one or more of the new microeconomic fields. Also notice that they all focus on areas within economics that are neither heterodox nor strictly neoclassical. Finally, notice that these are also books with a normative philosophical focus-they are not (at least primarily) historical or sociological; they are philosophical-but again, it is a local or micro-philosophical focus, not the universal "one rule fits all science" approach of earlier methodological work like that of Blaug and Hutchison. ${ }^{10}$

\footnotetext{
${ }^{10}$ This emphasis on new more pluralistic fields is also reflected in recent methodological books with a broader focus such as: introductory textbooks (Reiss 2013), more general contributions to the philosophy of economics (Ross 2014), alternative methodological approaches to empirical research (Reiss 2007), or works concerned with philosophical ideas beyond epistemology and philosophy of science (Davis 2011). One exception might appear to be Hausman 2012-since it emphasizes questions about preference, choice, and welfare relevant to traditional neoclassical theory-but even here much of the discussion concerns behavioral and experimental economics.
} 
As another, more personal, piece of evidence for this tendency, John Davis and I recently assembled a collection of papers by some of the most important contributors to the recent methodological literature: The Elgar companion to recent economic methodology (2011). The book has six sections: a section on methodological issues in contemporary choice theory, with papers on experimental economics, behavioral economics, and neuroeconomics; a second section on welfare economics, with many of the papers focusing on the economics of happiness and neo-hedonism; a third section on complexity, computational economics, and agent-based modeling; a fourth section on evolution and evolutionary economics; a fifth section on recent macroeconomics; and a final shorter section on the profession, the media, and the public. Notice that four sections out of six are dedicated to the areas of economics associated with the new pluralist mainstream in microeconomics. The last two sections are motivated in part by the recent macroeconomic and financial crisis and its impact on the profession (and the public's perception of the profession). The point is that when we attempted to put together a collection of papers that represented the best work in the most active research areas within recent economic methodology, we ended up with no papers on traditional neoclassical or heterodox topics. ${ }^{11}$ This is not to say that none of the authors offered a methodological defense of neoclassical economics-a few did-but it was never the main subject. To me this is a nice example of the fact that not only has pluralism of intellectual resources replaced the once-dominant "shelf of scientific philosophy" within economic methodology, a new more pluralist mainstream has replaced the "neoclassical shelf of scientific economics" as the dominant domain of inquiry regarding the important questions and concerns for methodological inquiry.

As a final bit of evidence for these recent methodological trends, it is useful to look at what seems to be the most influential methodological research by economic practitioners, that is, economists who are not also contributors to the general methodological literature: ${ }^{12}$

\footnotetext{
${ }^{11}$ The possible exceptions, depending on how one defines orthodox and heterodox, are the four papers in the macroeconomics section.

${ }^{12}$ For example the various authors of Bardsley, et al. 2010 are all practitioners in experimental and behavioral economics, but since many of the authors are also regular contributors to the methodological literature, I listed this book as recent economic methodology (not practitioner's commentary).
} 
Caplan and Schotter (2008). ${ }^{13}$ Again, as with the methodological literature previously discussed, this book focuses on new pluralist areas like experimental economics, behavioral economics, and neuroeconomics. The volume contains the controversial "mindless economics" essay by Faruk Gul and Wolfgang Pesendorfer (2008) and a series of comments on that paper by economists who are practitioners in the relevant, or closely related, fields. ${ }^{14}$ The Gull and Pesendorfer paper has been much discussed and elicits a wide range of responses, but it, and the commentaries on it, exhibit many of the same features as the recent literature from within the methodological community: the focus is on the new fields within microeconomics, it has a normativebut narrowly targeted-philosophical focus, and it exhibits a pronounced disinterest in most of the traditional methodological questions associated with either neoclassical or heterodox economics.

Two of the published responses from within the methodological community-Hausman (2008, 2012) and Ross (2011, 2014)-are quite different. Hausman is quite critical of not only Gul and Pesendorfer's methodological thesis, but also the revealed preference approach to choice theory on which it is based; while Ross is sympathetic to the revealed preference framework, but argues their methodological position needs to be strengthened in various ways. ${ }^{15}$ Although the main subject of the Gul and Pesendorfer paper is behavioral and neuroeconomics, they end up defending what they call standard neoclassical economics (although they define neoclassical in a very idiosyncratic way). This said-and even though they are defending a view they consider to be neoclassical-their work, like the commentaries on it, and most of the recent research from within the methodological community, demonstrates that the "hot" methodological topics are in these relatively new microeconomic fields. The bottom line is that one does not need to be completely convinced that neoclassical economics has been displaced from its dominant position within the mainstream to recognize that the most interesting and important methodological questions are no longer about either traditional neoclassical or

\footnotetext{
${ }^{13}$ Another example is Smith 2009, but it explores a much wider range of topics.

${ }^{14}$ Only one of the contributors to the volume was a regular contributor to the methodological literature, the philosopher Daniel Hausman.

${ }^{15}$ My own view is that while contemporary revealed preference theory is an important tool in empirical demand analysis-and may prove to be useful in other areas of empirical economics as well-Gul and Pesendorfer's methodological use of this literature is extremely problematic. See Hands 2013a, and 2013b, for example.
} 
heterodox economics, but rather, are about precisely the fields most often identified as representing a new more pluralistic mainstream.

This recent methodological literature is certainly less universalistic and more local, more naturalistic, and more sensitive to the particulars of the subfield within economics under investigation than the methodological literature of the period 1975-2000. Mark Blaug's book The methodology of economics (1980a/1992) provided a methodological assessment of various areas within economics, but the Popperian assessment tools were exactly the same for every single area. Do they make bold empirical conjectures and attempt to falsify them? If yes, then it is good science, and if no, then it is bad science (full stop). This is not the approach that is taken in most of the recent literature. A second point about this recent literature is that while it does exhibit the tendency to move away from the universalistic, and toward the particularistic, it is important that this movement does not imply an absence of philosophical rigor, a lack of normative assessment, or imply that anything goes. Not having a single narrow standard-what Deirdre McCloskey (1994) aptly called 3" x 5" card philosophy of science-does not mean having no philosophical standards at all. Again all of the works mentioned earlier are good examples of this.

\section{CONCLUSION}

It is probably useful to conclude by summarizing the various parts of the argument I have presented. The earlier methodological literature like the work of Blaug and Hutchison was aggressively normative in its style, and negative in its assessment. The message was "this is what economists must do in order to produce scientific knowledge about the economy and economic behavior, and you (either neoclassical or heterodox) are not doing it". And yet the methodological rules it endorsed were offered at such an abstract and universalistic level, and so insensitive to the interests and concerns of the economists actually working in the various specific subfields within economic science, that it had essentially nothing to offer (either neoclassical or heterodox) practitioners about how disciplinary practice might be improved. There were very general injunctions to "test more" and "be more realistic", but there was no practical guidance to a group of economists working in a particular subfield struggling to extract as much knowledge as possible from the models and the data at their disposal while facing a wide range of subfield- and context-specific constraints. This is very different from 
the vast majority of the methodological literature of the last decade. For most of the recent research the domain of inquiry is neither neoclassical nor heterodox economics in general, but rather the many currently expanding subfields in microeconomics I have been discussing. In addition, it is not based on grand universalistic philosophy of science; it is applied philosophical inquiry aimed at the practical methodological issues of practitioners within specific subfields and sensitive to the issues, challenges, and constraints they face. It is important to note that while this more recent methodological work is local and close-focused, it is often critical-constructively critical-and it is philosophy-based. The argument that was often made in the earlier literature-Blaug 1994 is a good example-was that if one stepped down even a few steps from grand universalistic (and 3" x 5" card) rules for how all science must be done, one was necessarily on a slippery slope and will necessarily end up doing pure history, or sociology of science, or science studies, or some other type of inquiry that was not grounded in the (normative) philosophical justification of scientific knowledge and practice. Of course history, science studies, and sociological or anthropological studies of science (including economics) are interesting and important intellectual endeavors, but they do in fact have different goals, issues, and concerns than work grounded in normative philosophy. The point is that the recent literature in economic methodology clearly demonstrates that the entire slippery slope argument was an illusion. One can do local, subfield- and context-sensitive, studies in economic science that are philosophy-based and critical of current practice. Not only does one not need to give up on normative issues and philosophical justification, but one can produce work that actually offers the practicing economist some ideas about how knowledge production within specific subfields might be improved.

To conclude: there has been a lot of expansion and a lot of change within the field of economic methodology during the last few decades. During these years the field has changed its general philosophical focus from universal rules borrowed from the shelf of scientific philosophy to local practical advice grounded in the interests and concerns of particular sub-fields; and it has changed its domain of inquiry from neoclassical and heterodox economics in general to the more pluralistic microeconomic approaches at the edge of the current research frontier. Since interests always matter in the developmental path of any research program-within a particular science or within the study of a particular 
science-these changes will, and to some extent already have, contributed to the re-alignment of interests behind the field of economic methodology. My guess is that these changes will contribute to the steady growth and increased health of the field, but one never knows. Economic theorists have recently re-discovered path-dependency and the significance of context; we should not forget that these things matter to the future of economic methodology as well.

\section{REFERENCES}

Ashrof, Nova, Colin F. Camerer, and George Loewenstein. 2005. Adam Smith's behavioral economics. Journal of Economic Perspectives, 19 (3): 131-145.

Bardsley, Nicholas, Robin Cubitt, Graham Loomes, Peter Moffatt, Chris Starmer, and Robert Sugden. 2010. Experimental economics: rethinking the rules. Princeton: Princeton University Press.

Blaug, Mark. 1958. Ricardian economics: a historical study. New Haven (CT): Yale University Press.

Blaug, Mark. 1976. Kuhn versus Lakatos, or paradigms versus research programmes in the history of economics. In Method and appraisal in economics, ed. S. J. Latsis. Cambridge: Cambridge University Press, 149-180.

Blaug, Mark. 1980a. The methodology of economics: or how economists explain. Cambridge: Cambridge University Press.

Blaug, Mark. 1980b. Methodological appraisal of Marxian economics. Amsterdam: Elsevier Science.

Blaug, Mark. 1990. Economic theories, true or false?: essays in the history and methodology of economics. Aldershot: Edward Elgar.

Blaug, Mark. 1992 [1980]. The methodology of economics: or how economists explain [2nd edition]. Cambridge: Cambridge University Press.

Blaug, Mark. 1994. Why I am not a constructivist: confessions of an unrepentant Popperian. In New directions in economic methodology, ed. R. E. Backhouse. London: Routledge, 109-136.

Blaug, Mark. 1997. Ugly currents in modern economics. Policy Options, 17 (7): 2-5.

Blaug, Mark. 2002. Is there really progress in economics? In Is there progress in economics?, eds. S. Boehm, C. Gehrke, H. D. Kurz, and R. Sturn. Cheltenham (UK): Edward Elgar, 21-41.

Blaug, Mark. 2003. The formalist revolution of the 1950s. Journal of the History of Economic Thought, 25 (2): 145-156.

Blaug, Mark. 2009. The trade-off between rigor and relevance: Sraffian economics as a case in point. History of Political Economy, 41 (2): 219-247.

Boland, Lawrence A. 1982. The foundations of economic method. London: George Allen \& Unwin.

Bruni, Luigino, and Robert Sugden. 2007. The road not taken: how psychology was removed from economics, and how it might be bought back. Economic Journal, 117 (516): 146-173.

Caldwell, Bruce J. 1982. Beyond positivism: economic methodology in the twentieth century. London: George Allen \& Unwin. 
Caldwell, Bruce J. 2009. A skirmish in the Popper wars: Hutchison versus Caldwell on Hayek, Popper, and methodology. Journal of Economic Methodology, 16 (3): 315324.

Camerer, Colin F., and George Loewenstein. 2004. Behavioral economics: past, present, and future. In Advances in behavioral economics, eds. C. F. Camerer, G. Loewenstein, and M. Rabin. Princeton: Princeton University Press, 3-51.

Caplan, Andrew, and Andrew Schotter (eds.). 2008. The foundations of positive and normative economics. Oxford: Oxford University Press.

Colander, David. 2000. The death of neoclassical economics. Journal of the History of Economic Thought, 22 (2): 127-144.

Colander, David, Richard P. F. Holt, and Barkley Rosser. 2008. The changing face of mainstream economics. The Long Term View, 7 (1): 31-42.

Davis, John B. 2006. The turn in economics: neoclassical dominance to mainstream pluralism. Journal of Institutional Economics, 2 (1): 1-20.

Davis, John B. 2008. The turn in recent economics and return of orthodoxy. Cambridge Journal of Economics, 32 (3): 349-366.

Davis, John B. 2011. Individuals and identity in economics. Cambridge: Cambridge University Press.

Davis, John B., and Marcel Boumans. 2010. Economic methodology: understanding economics as a science. London: Palgrave Macmillan.

Davis, John B., and D. Wade Hands. 2011. The Elgar companion to recent economic methodology. Cheltenham (UK): Edward Elgar Publishing.

Dow, Sheila C. 2011. Heterodox economics: history and prospects. Cambridge Journal of Economics, 35 (6): 1151-1165.

Friedman, Milton. 1953. The methodology of positive economics. In Essays in positive economics, Milton Friedman. Chicago: University of Chicago Press, 3-43.

Garegnani, Pierangelo. 2011. On Blaug ten years later. History of Political Economy, 43 (3): 591-605.

Guala, Francesco. 2005. The methodology of experimental economics. Cambridge: Cambridge University Press.

Gul, Faruk, and Wolfgang Pesendorfer. 2008. The case for mindless economics. In The foundations of positive and normative economics: a handbook, eds. A. Caplin, and A. Schotter. Oxford: Oxford University Press, 3-39.

Hands, D. Wade. 1994. Blurred boundaries: recent changes in the relationship between economics and the philosophy of natural science. Studies in History and Philosophy of Science, 25 (5): 751-772.

Hands, D. Wade. 2001. Reflection without rules: economic methodology and contemporary science theory. Cambridge: Cambridge University Press.

Hands, D. Wade. 2006. Integrability, rationalizability, and path-dependency in the history of demand theory. In Agreement on demand: consumer theory in the twentieth century, eds. P. Mirowski, and D. W. Hands. Durham (NC): Duke University Press [annual supplement to volume 38 of History of Political Economy], 153-185.

Hands, D. Wade. 2010. Economics, psychology, and the history of consumer choice theory. Cambridge Journal of Economics, 34 (4): 633-648.

Hands, D. Wade. 2011. Back to the ordinalist revolution: behavioral economic concerns in early modern consumer choice theory. Metroeconomica, 62 (2): 386-410. 
Hands, D. Wade. 2013a. Foundations of contemporary revealed preference theory. Erkenntnis, 78 (5): 1081-1108.

Hands, D. Wade. 2013b. GP08 is the new F53: Gul and Pesendorfer's methodological essay from the viewpoint of Blaug's Popperian methodology. In Mark Blaug: rebel with many causes, eds. M. Boumans, and M. Klaes. Cheltenham (UK): Edward Elgar, 245-265.

Hausman, Daniel M. 1981. Capital, profits, and prices: an essay in the philosophy of economics. New York: Columbia University Press.

Hausman, Daniel M. 1988. An appraisal of Popperian methodology. In The Popperian legacy in economics, ed. N. De Marchi. Cambridge: Cambridge University Press, 6585.

Hausman, Daniel. 2008. Mindless or mindful economics: a methodological evaluation. In The foundations of positive and normative economics: a handbook, eds. A. Caplin, and A. Schotter. Oxford: Oxford University Press, 125-151.

Hausman, Daniel. 2012. Preference, value, choice, and welfare. Cambridge: Cambridge University Press.

Hempel, Carl G. 1965. Aspects of scientific explanation and other essays in the philosophy of science. New York: Free Press.

Heukelom, Floris. 2014. Behavioral economics: a history. Cambridge: Cambridge University Press.

Heukelom, Floris, and Esther-Mirjam Sent. 2010. The economics of the crisis and the crisis of economics: lessons from behavioral economics. Krisis, (3): 26-38.

Hutchison, Terence W. 1938. The significance and basic postulates of economic theory. London: Macmillan.

Hutchison, Terence W. 1981. The politics and philosophy of economics: Marxians, Keynesian, and Austrians. New York: New York University Press.

Hutchison, Terence W. 1988. The case for falsificationism. In The Popperian legacy in economics, ed. N. De Marchi. Cambridge: Cambridge University Press, 169-181.

Hutchison, Terence W. 1992. Changing aims in economics. Oxford: Blackwell.

Hutchison, Terence W. 2000. On the methodology of economics and the formalist revolution. Cheltenham (UK): Edward Elgar.

Hutchison, Terence W. 2009. A formative decade: methodological controversy in the 1930s. Journal of Economic Methodology, 16 (3): 297-314.

Kahneman, Daniel. 2003. Maps of bounded rationality: psychology for behavioral economics. American Economic Review, 93 (5): 1449-1475.

Kahneman, Daniel, Jack L. Knetsch, and Richard Thaler. 1991. Anomalies: the endowment effect, loss aversion, and status quo bias. Journal of Economic Perspectives, 5 (1): 193-206.

Kahneman, Daniel, and Amos Tversky (eds.). 2000. Choices, values, and frames. Cambridge: Cambridge University Press.

Kahneman, Daniel, Peter P. Wakker, and Rakesh Sarin. 1997. Back to Bentham?: explorations of experienced utility. The Quarterly Journal of Economics, 112 (2): 375-405.

Kurz, Heinz D., and Neri Salvadori. 2011. In favor of rigor and relevance: a reply to Mark Blaug. History of Political Economy, 43 (3): 608-616.

Latsis, Spiro J. (ed.). 1976. Method and appraisal in economics. Cambridge: Cambridge University Press. 
Lazzarini, Andrés, and Diego Weisman (eds.). 2012. Perspectives on epistemology of economics: essays on methodology of economics. Buenos Aires: CIECE, UBA.

Lee, Frederic S. 2009. A history of heterodox economics: challenging the mainstream in the twentieth century. London: Routledge.

McCloskey, Deirdre M. 1994. Knowledge and persuasion in economics. Cambridge University Press.

Nagel, Ernest. 1961. The structure of science. New York: Harcourt, Brace \& World.

Popper, Karl R. 1959. The logic of scientific discovery. New York: Basic Books.

Popper, Karl R. 1965 [1963]. Conjectures and refutations. New York: Harper \& Row.

Popper, Karl R. 1976. Unended quest: an intellectual autobiography. LaSalle (IL): Open Court.

Popper, Karl R. 1994. The myth of the framework: in defense of science and rationality. London: Routledge.

Reiss, Julian. 2007. Error in economics: towards an evidence based methodology. New York: Routledge.

Reiss, Julian. 2013. Philosophy of economics: a contemporary introduction. New York: Routledge.

Robbins, Lionel. 1932. An essay on the nature and significance of economic science. London: Macmillan \& Co.

Robbins, Lionel. 1952. An essay on the nature and significance of economic science [Reprint of 1935 2nd Edition]. London: Macmillan \& Co.

Rosenberg, Alexander. 1976. Microeconomic laws: a philosophical analysis. Pittsburgh (PA): University of Pittsburgh Press.

Ross, Don. 2005. Economic theory and cognitive science. Cambridge (MA): MIT Press.

Ross, Don. 2011. Estranged parents and a schizophrenic child: choice in economics, psychology, and neuroeconomics. Journal of Economic Methodology, 18 (3): 217231.

Ross, Don. 2014. Philosophy of economics. New York: Palgrave Macmillan.

Samuelson, Paul A. 1964. Theory and realism: a reply. American Economic Review, 54 (5): 736-739.

Samuelson, Paul A. 1965. Professor Samuelson on theory and realism: reply. American Economic Review, 55 (5): 1164-1172.

Santos, Ana. 2010. The social epistemology of experimental economics. London: Routledge.

Santos, Ana C. 2011. Behavioural and experimental economics: are they really transforming economics? Cambridge Journal of Economics, 35 (4): 705-728.

Sent, Esther-Mirjam. 2004. Behavioral economics: how psychology made its (limited) way back into economics. History of Political Economy, 36 (4): 735-760.

Smith, Vernon. 2008. Rationality and economics: constructivist and ecological forms. Cambridge: Cambridge University Press.

Sugden, Robert. 2006. Hume's non-instrumental and non-propositional decision theory. Economics and Philosophy, 22 (3): 365-391.

Thaler, Richard H. 1980. Toward a positive theory of consumer choice. Journal of Economic Behavior and Organization, 1 (1): 39-60. Reprinted in Choices, values, and frames [2000], eds. D. Kahneman, and A. Tversky. Cambridge: Cambridge University Press. 
Tversky, Amos, and Daniel Kahneman. 1991. Loss aversion in riskless choice. Quarterly Journal of Economics, 106 (4): 1039-1061. Reprinted in Choices, values, and frames [2000], eds. D. Kahneman, and A. Tversky. Cambridge: Cambridge University Press. Wong, Stanley. 1978. The foundations of Paul Samuelson's revealed preference theory. Boston: Routledge and Kegan Paul.

D. Wade Hands is distinguished professor of economics at the University of Puget Sound in Washington state and has taught history of economic thought for over thirty years. He has written on a wide range of topics in the history of economic thought and economic methodology. He is co-editor of The Journal of Economic Methodology and the author of Reflection without rules: economic methodology and contemporary science theory (Cambridge University Press, 2001). His Agreement on demand: consumer choice theory in the 20th century, edited with Philip Mirowski, was published in 2006 by Duke University Press and The Elgar companion to recent economic methodology, edited with John B. Davis, was published in 2011.

Contact e-mail: <hands@pugetsound.edu> 